NK

9283

Yo

$$
\text { +B 3ь几 } 202
$$



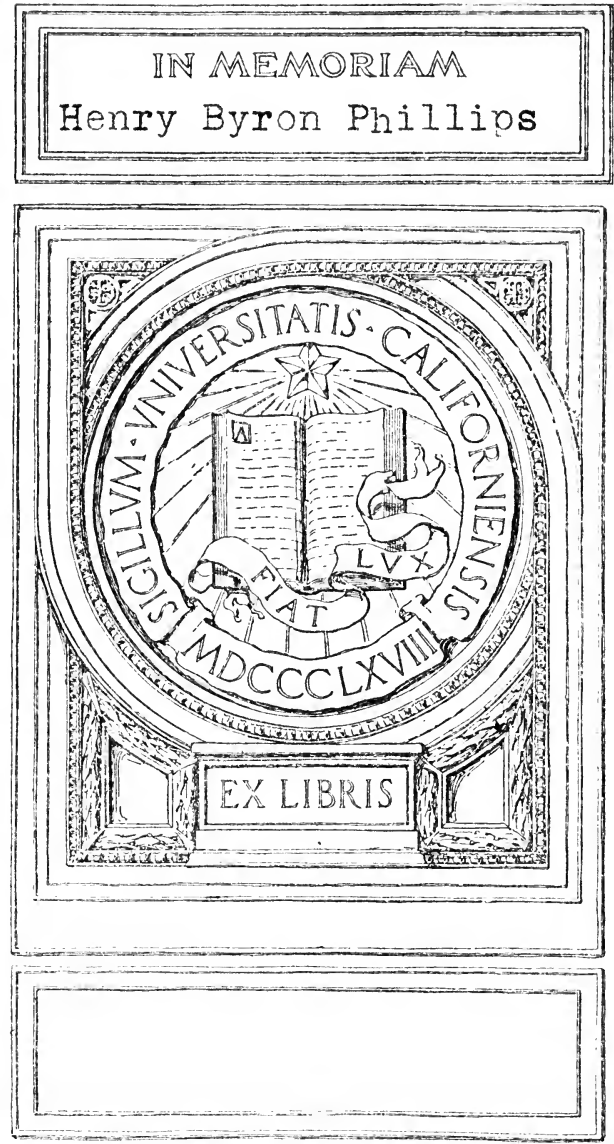


\title{
洋平太川金舊國美大 會覽博馬拿巴國萬
}

\author{
品寒土女壽沈余國中
}

書明說像穌耶綀

\section{PANAMA PACIFIC INTERNATIONAL EXPOSITION}

\section{EMBROIDERED PORTRAIT OF JESUS}

\author{
EXHIBITED BY \\ Mrs. Yu Shen-sheo \\ CHINA
}

匢代局書華中海上

Printed at the Chung Hwa Book Co., Lto.

Shianghai 


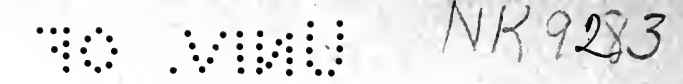

○ी

Sitis.

Atury Bysm

Bhillifs. 
像省之士女告沈余家術美紼刺國中

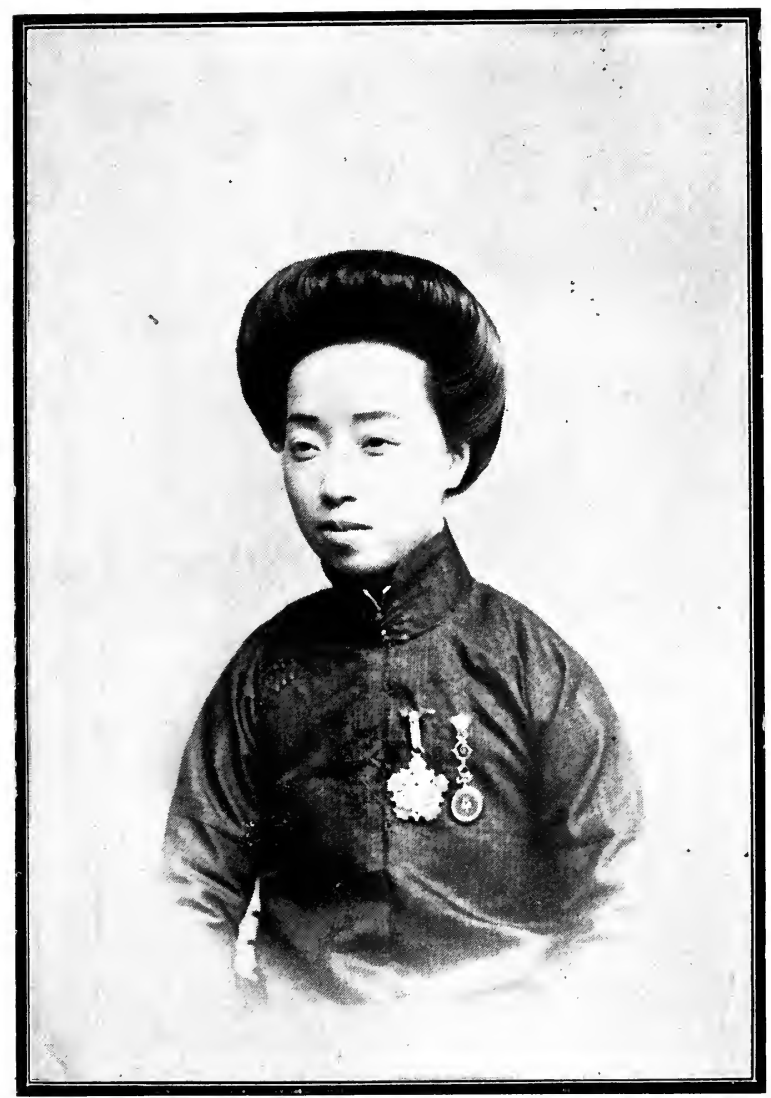

Portrait of Mrs. Y 1 Shen-sheo, a Chinese Lady Artist in Embroidery. 

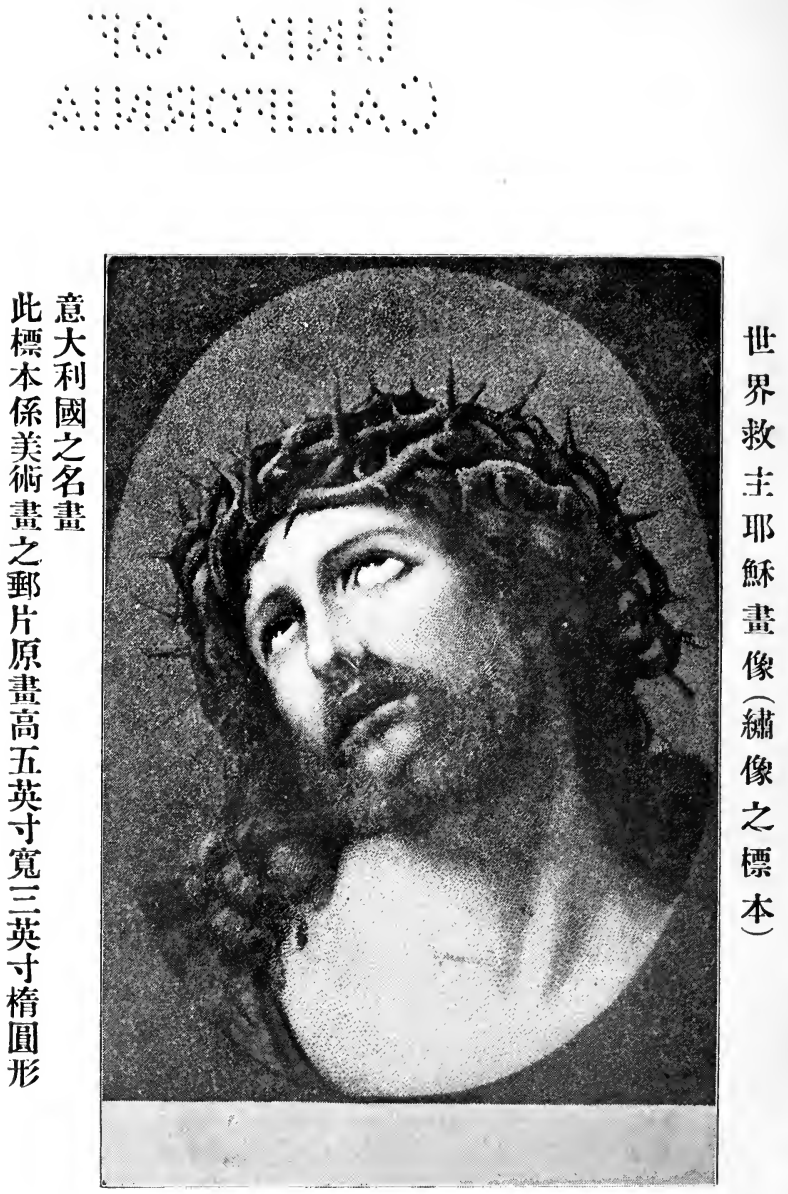

The Original of the Embroidered

Portrait of Jesus, a reproduction of

a famous Italian painting on a post-card ( $5^{\prime \prime} \times 3^{\prime \prime}$, oval in shape). 


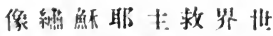

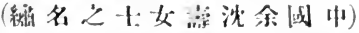

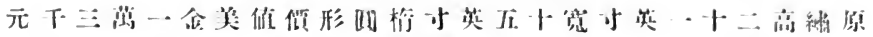

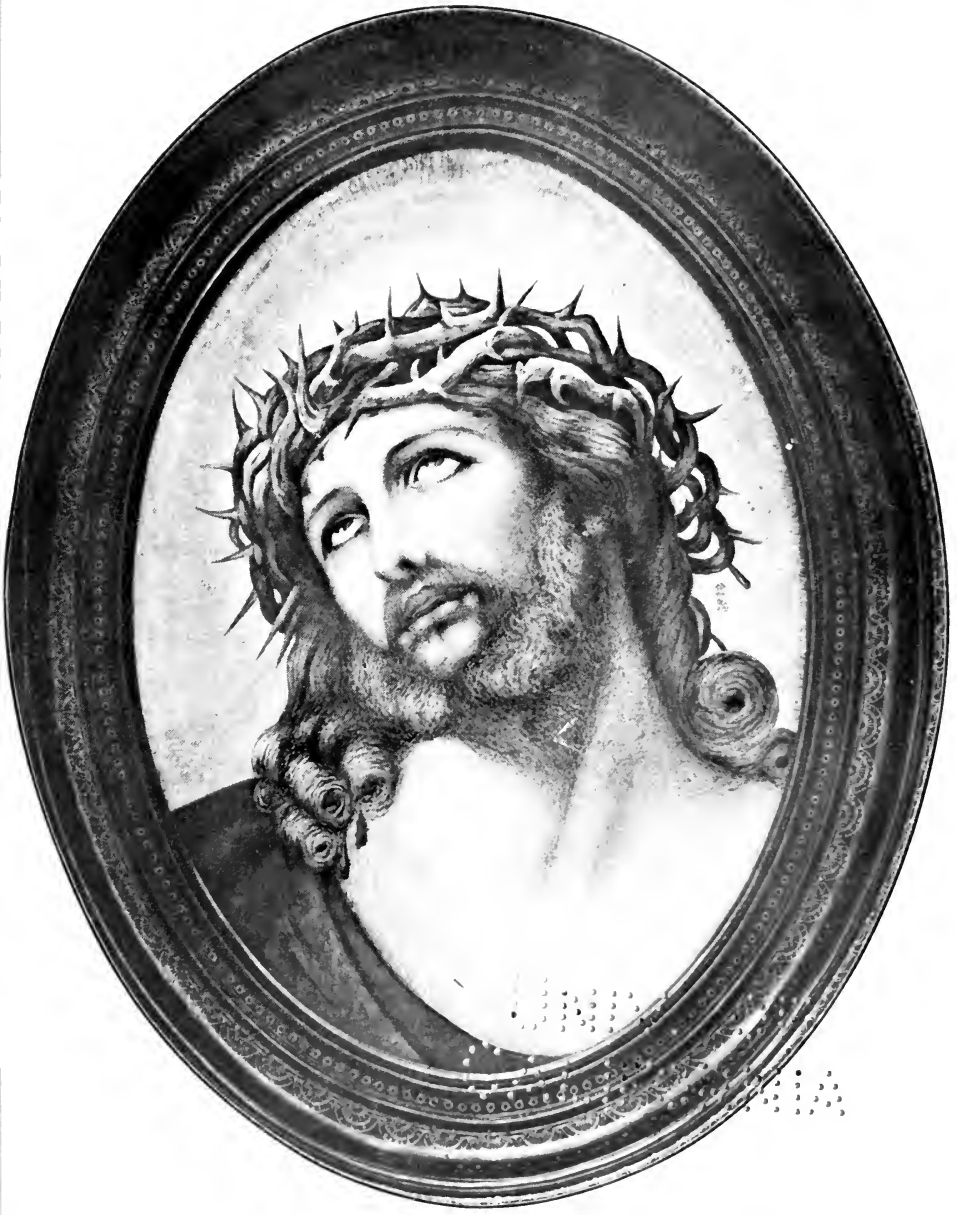

Portrait of Jesus on Crucitication, embroidered hy Mrs. Vu Shensheo, China $\left(21^{\prime \prime} \times 15^{\prime \prime}\right.$. wial in shilpe. value $\leq 1: 3,(0)(0)$. 


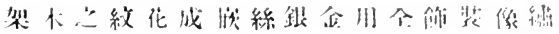

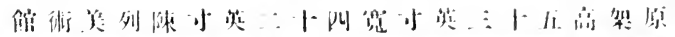

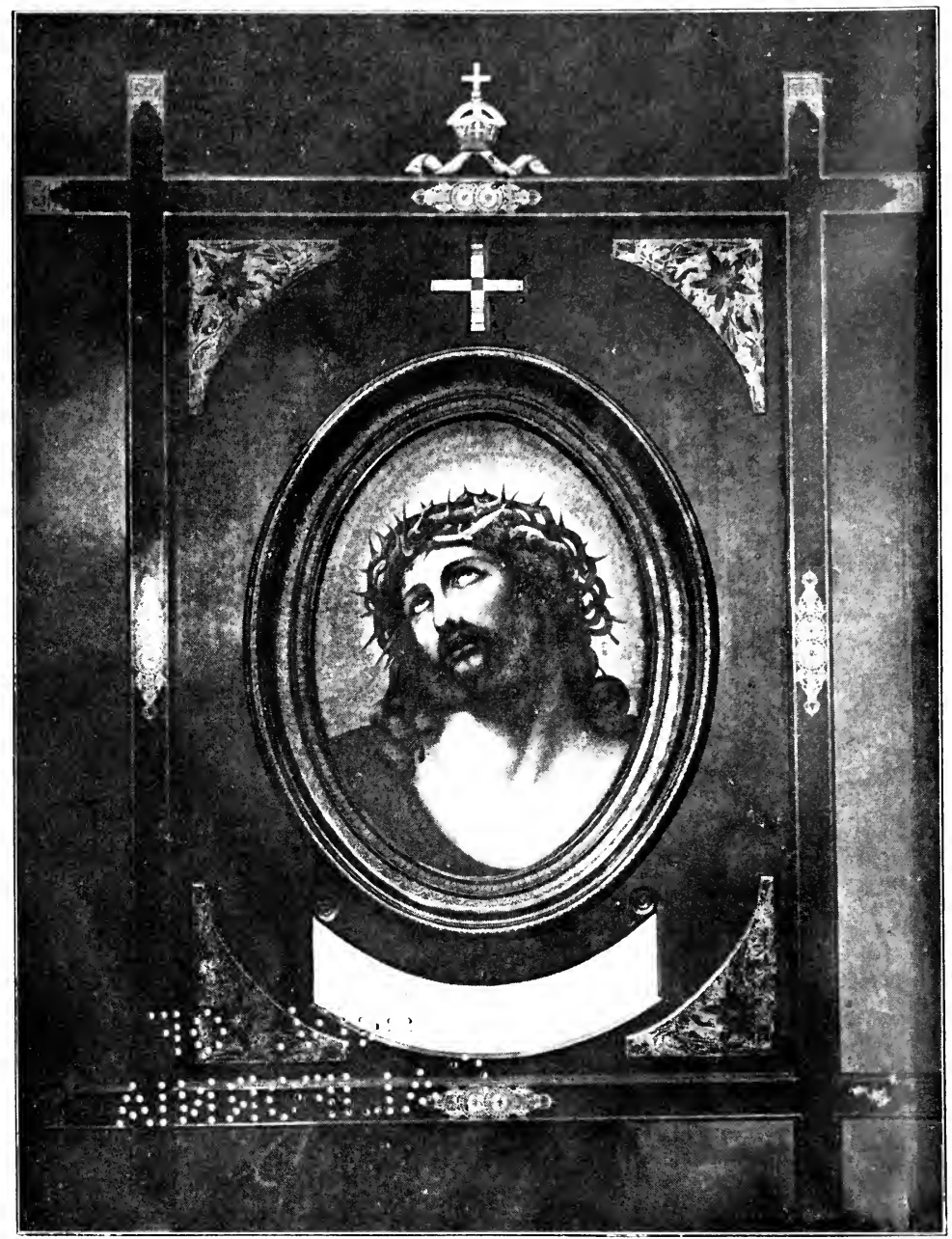

Wooden Frame of the Portrait of Jesus (.):3" $\times+2{ }^{\prime \prime}$. inlatel with gold and silver. ('xhibited in the Arts Building). 


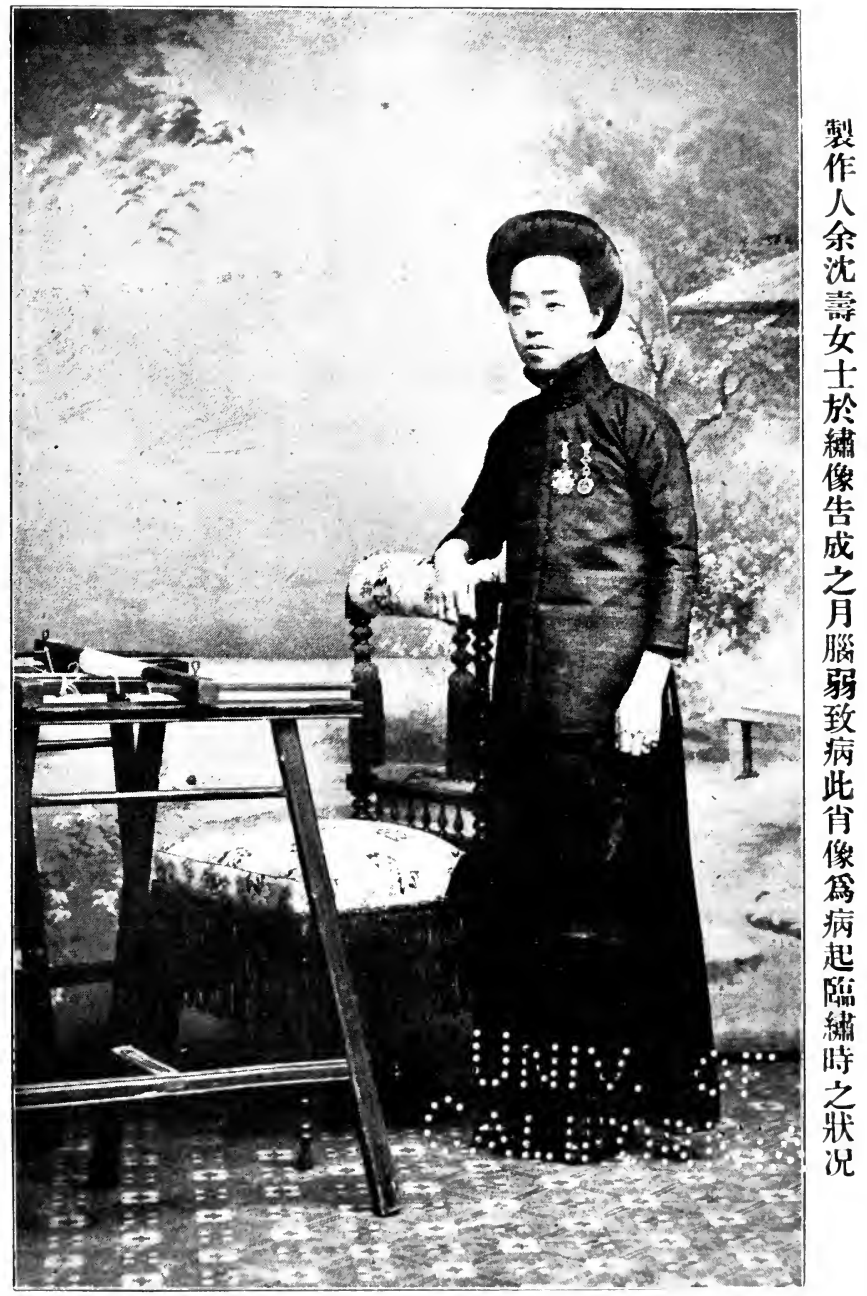

Photograph of Mrs. Yu shen-sheo. completing her work on the Portrait of . Jesus after her recovery from woakness of brain during the last month of her work. 


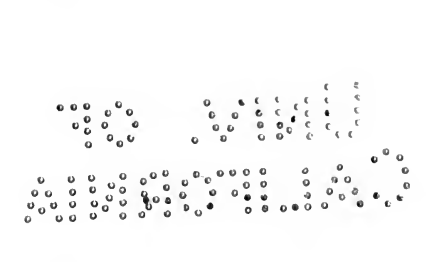


no color added by retouching after the work was completed.

6. The portrait is oval in shape. Its dimensions are twenty-one and half by sixteen inches. The dimensions of its wooden frame are fifty-four by forty inches.

7. The design was modeled after a small reprint ( 5 by 3 inches) of a famous painting. The reprint was first enlarged and copied on the silk with brush in faint Indian ink, and then the work of embroidering was carefully executed. Most of the floss-silk was dyed by the embroiderer herself; only a very small part of it was bought from market.

8. If good care is given to the portrait, mere exposure to light will in no way spoil its colors, but on the contrary will rather increase its artistic effect. 
9. In this piece of embroidery, the mingling of various shades of colors is exactly the same as in painting. Enbroidering, however, is more difficult than painting.

10. The frame of this portrait is made of Chinese hard wood of the best quality, similar to ebony and mahogany. The wood is well seasoned and will neither warp nor crack.

11. The metallic work on the frame is of genuine gold and silver threads. It will not lose its brilliancy, if it is given proper care.

12. The following is an account of the embroiderer, Mrs. Yu Shen-sheo. 


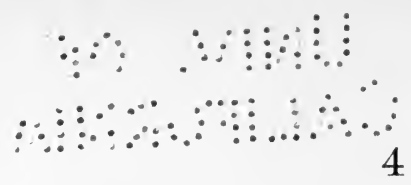

\section{A BRIEF ACCOUNT OF MRS. YU SHEN-SHEO'S ACCOM- PLISHMENTS IN THE ART OF EMBROIDERY}

Mrs. $\mathrm{Yu}$ is the foremost Chinese lady artist in embroidery. Her productions have won for her at different occasions prizes and recognition from persons of the highest distinction.

In 1904 some embroidery work of Mrs. Yu's design and make was presented by the authorities in Peking to the Emperor Kwangsii and the Empress Dowager. Her mastery of the embroidery art was given special recognition in an Imperial decree which decorated Mrs. Yu with a decoration of the fourth order. She was further favored with a rare gift from the Empress Dowager. Later by Imperial order 
Mrs. Yu was sent to investigate into the art of embroidery in Japan. Upon her return she was appointed instructor in embroidery to the members of the Imperial family.

In the year 1910 the Chinese Government held its first National Exposition in Nanking. Mrs. Yu, for her embroidery work, was awarded a first prize. Soon she and her husband were appointed by the Chinese Government as special investigators into the work of embroidery in China.

In 1912 a portrait of the Italian Emperor and Empress embroidered by Mrs. $\mathrm{Yu}$ was exhibited at the International Exposition in Italy. The work was judged to be worth three thousand pounds sterling. For this Mrs. Yu was awarded a grand prize. Later when the portrait was 
presented by the Chinese Government to the Emperor of Italy, the Chinese Emperor was decorated with the order of St. Mary and Mrs. Yu was rewarded a gold watch bearing the coat of arms of the Italian Imperial fimily.

In the year 1914, Mrs. Yu was invited to teach embroidery in the Girls' Industrial School in Tungchow, which position she is now still holding.

In view of her high attainment in the art of embroidery, Mrs. Yu has been appointed by H. E. Chang Chien, Minister of the Department of Agriculture and Commerce, a delegate to the Panama International Exposition.

Mrs. Yu is now organizing an embroidery institute in Shanghai for the purpose of getting the Chinese lady artists in embroidery to bring forth the best Chinese 
talent in their art and to offer to the world the best product of Chinese embroidery.

The price of a single piece of embroidery ranges from one dollar to ten thousand dollars gold. If any one in America wishes to be the sole agent of this Institute, Mrs. Yu will be glad to make a contract with him when she is at the Exposition with her husband in 1915, or afterwards to receive applications at the following address :-

Mr's. Yu Shrin-sheo,

Girls' Industrial School,

Tungchou, Kian!su, China. 


\section{FURTHER NOTES ON THE PORTRAIT OF JESUS}

This piece of embroidery was once exhibited in Tungchow, Kiangsu. A number of western connoisseurs were asked to estimate the value of the work by H. E. Chang Chien, the foremost industrial promoter of China and the present Minister of Agriculture and Commerce. All of them agreed that the work is worth at least a hundred thousand dollars, as the face of Jesus shows the real significance of his sufferings, the boundless love for mankind.

The embroiderer, however, for her love of Christ, will follow the example of the famous German artist ("Stanbo" of the city "Tustu," according to the Chinese translation of an important religious work published by the Religious Tract Society, 
London) in fixing a lower price for the portrait, the price of thirteen thousand dollars.

If in one of the greatest churches of Europe or America this portrait can replace the lost work of the German artist, which was destroyed in a fire some decades ago, there will be certainly no lack of such repentent sinners as the fomder of the German Society of Friends ("Sensintu," according to the religious work above referred to). What should we do, then, but to thank God for having given to the world these two artists in the space of orer a hundred years!

PRINTED AT THE CHUNG HWA BOOK CO., LTD., 5) HONAN ROAD, Shanghai 
耶殆堂因受作苦驗此 穌亦乎公苦人之之紼

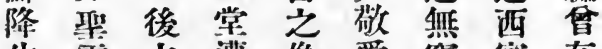

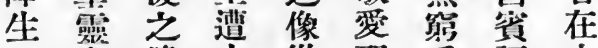

一有陒火從耶愛評中

九所斯隨廉穌心論

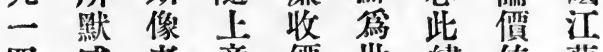

四感者帝 價世紼值 蘇

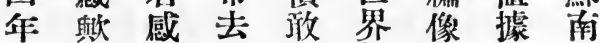

製孚突捘 救 䨘云通

作 童此斯圭篇此州

出㶾 紼義因世紼開

品當 像亦思界 精 展

人不出從數空神覽

中 之現廉百前能睤

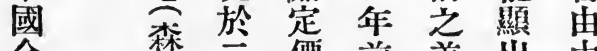

余

洸

䂧三價 前 夆

出中

世

界

多美德峏 救 國

年

救

櫓

紼

你

就

世金國較主 發

其 紀 - 都 原 受 起

人之萬士畜 刑 實

也中多更時業

而 國 千 城 難 面 家

製 不元名能上現

作能 嗟 畫可痛任

人自乎家貴苦 農

後有 方共從 商

森或登声價 痛 部

省能堡 保 值 苦 總

多永 劣 恋至 中 長

君 永点栾省現謇

之存䡒敬士救 游

生於於愛萬主請

線 歐 數 耶 元 代 有

百美十穌云世學

俆大年並惟人問

年 教 前 一 製 受 經 
居一靠正於工於

传元金在一傅一

處。二虫九習九

开元國二所一

中年起上五表四

國爽點。海 年0 任。 年。

江贵至組由䇰 南

蘚鿖莒織中刺中

省參元國紼國

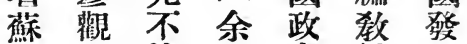

州 時。等。沉府 筫。起

城即如壽派㴦

丙可曋共基

黑面算美夫芜。

醫訂業紼媂現

科合家货赴任

街。同願商大農

辦經店。美商

通理。理 乙國部

脚或余會隻總

處。以沈鬲金長。

一後簅南山江.

中等商北太政

國函店省平南

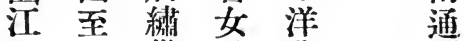

蘚中货弟茧州

省 國在子。國

南下贵精巴

通開國慗拿

州地票各楼

城 址售 種 博

队處者。紼覽

女均筡貨。會

工可。作每

傳現人件觀

俏慜夫僄美

所。作 媂 值。峪。

一人於自現

蔍。四

聘

至

南

通

州o

充

栠 
以意場。於國於家人太生 故大震一繡一特之后於 有利得九㽞儿設姓。御 -

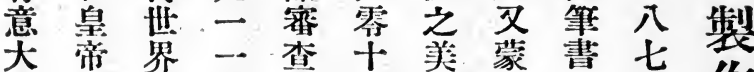
利皇至年。官。年。術政 八四作 國宫大製 世...清紼府尺年。

皇親 榮 作

家筆誉。人

徽 函之紼

章 謝、点

之中卓䒿

金 國絶利

剛 政 獎。國

鍇 府。清 皇

金 並 政帝

表回府皇

一 䁮 師 后

件。中 以省

以國中 像。

第 政 國 值

特 府 政 偵

別 以府英

珍最名金

貴高 義。兰

之 級 墏 手

記之紼 磅

三念䚈 像 赴

唱。琶 特 意

梨 賠 猁

瓚大國

星。利 都

另 皇 期

獎 帝 萬

製 皇 國

作 后。鉒

人 蒙會
政 I. 奏 長

府科 請

開 總 皇

第敎 帝

- 習。 唄

次 其:

i)

南头四賜清

洋交等其 國

勸 學 商 夫 政

業 科 勳。婦。府

會。㦛 由 製 以

製人政作 製

作 府人。作

人余派即人

紼 冰 其 以 紼

品。臣。关 䩧 品

零 媂。学 進

得今原同第 呈

- 紫名 往 名。清

等 名泉百 以 國

奏學熊本作皇

獎。充 國 永 太

並 繡 考遠 后

奏工察紀皇

請 科 美 念口帝。

派 總 戈。 余

其 理。回峹旨

夫し國嘉

婦

充

後。係 獎。

充 製 蒙

全 皇 作 皇 


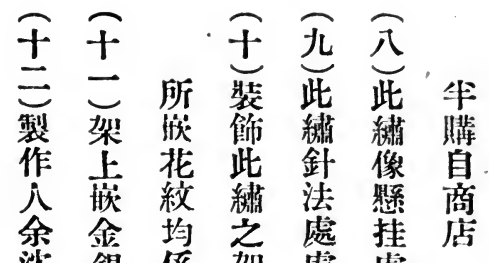

沈銀係架處處

諱 絲 基 係 烄 如

女處金中輔 無

吉每 銀 國 如 特

磨拿絲最中别

糜 用

史 蠟

点國学

附 布

之舅篦

載 拂

於 拭

木之永

後

黑筆 不

色 筆 變

度者有壤

永第意且

久楟惟歷

元槄時

彩 紫筆

熖色易久

發 者旅其

雼針色

楠 線 意

木 難 雅

水 旋

浸 故

不名

腐 綝

日 㢾

輓較

不名

裂 恝

架 尤 


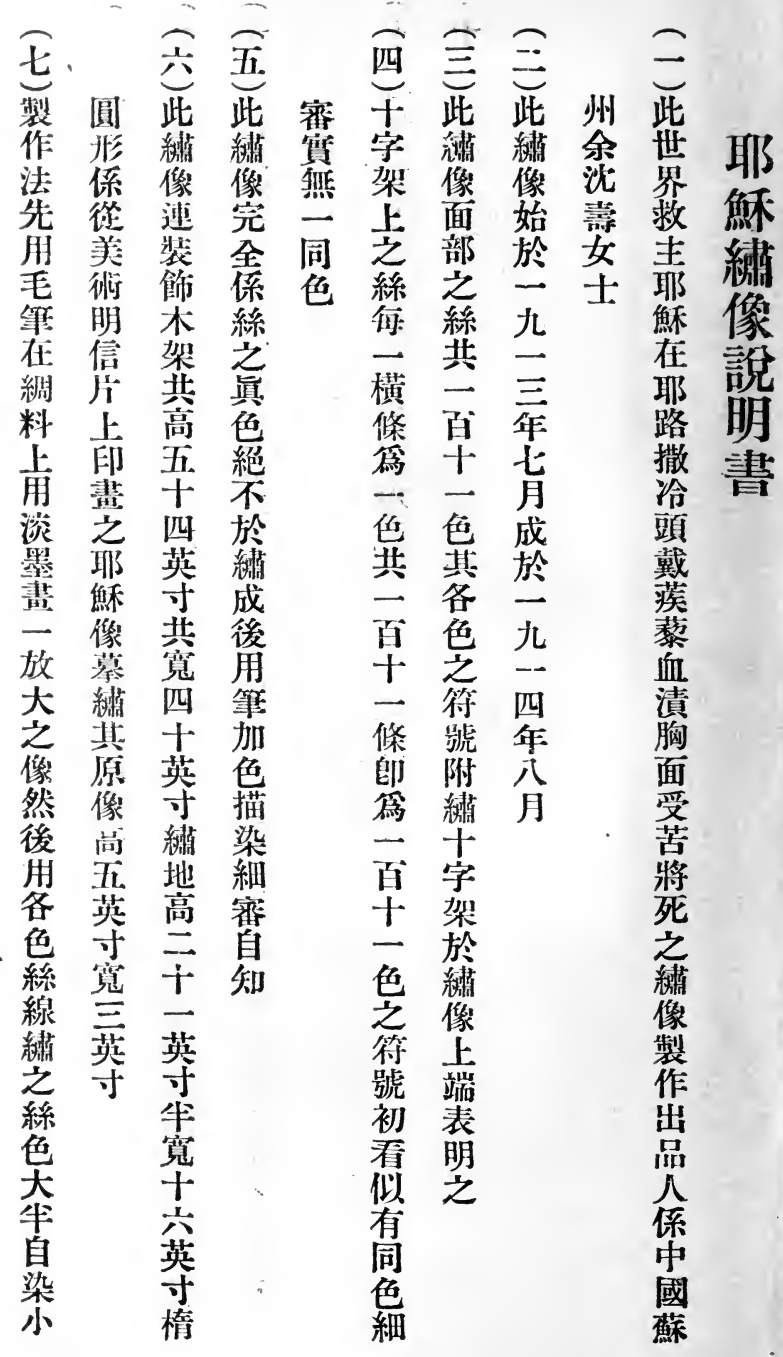




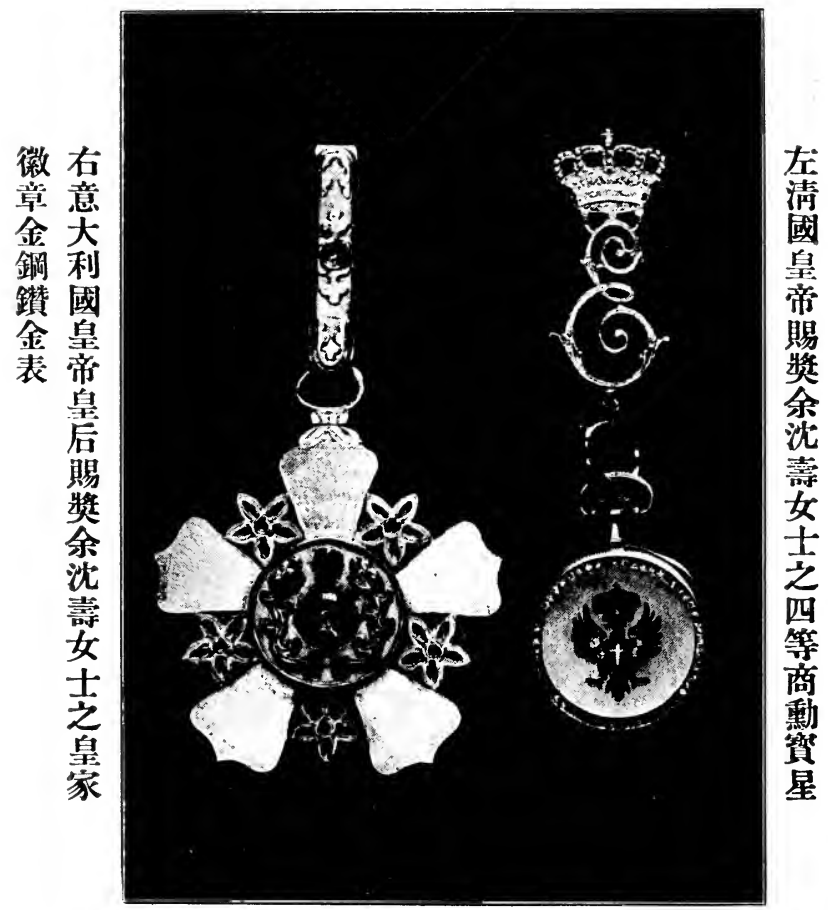

Left-Decoration of the Fourth Order, awarded to Mrs. Yu Shen-sheo by the Emperor Kwangsï of the 'Ts'ing Dynasty.

Right-Gold watch bearing the Coat of Arms of the Italian Imperial Family, awarded to Mrs. Yu Shen-sheo by the Emperor and Empress of Italy. 


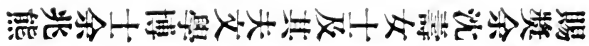

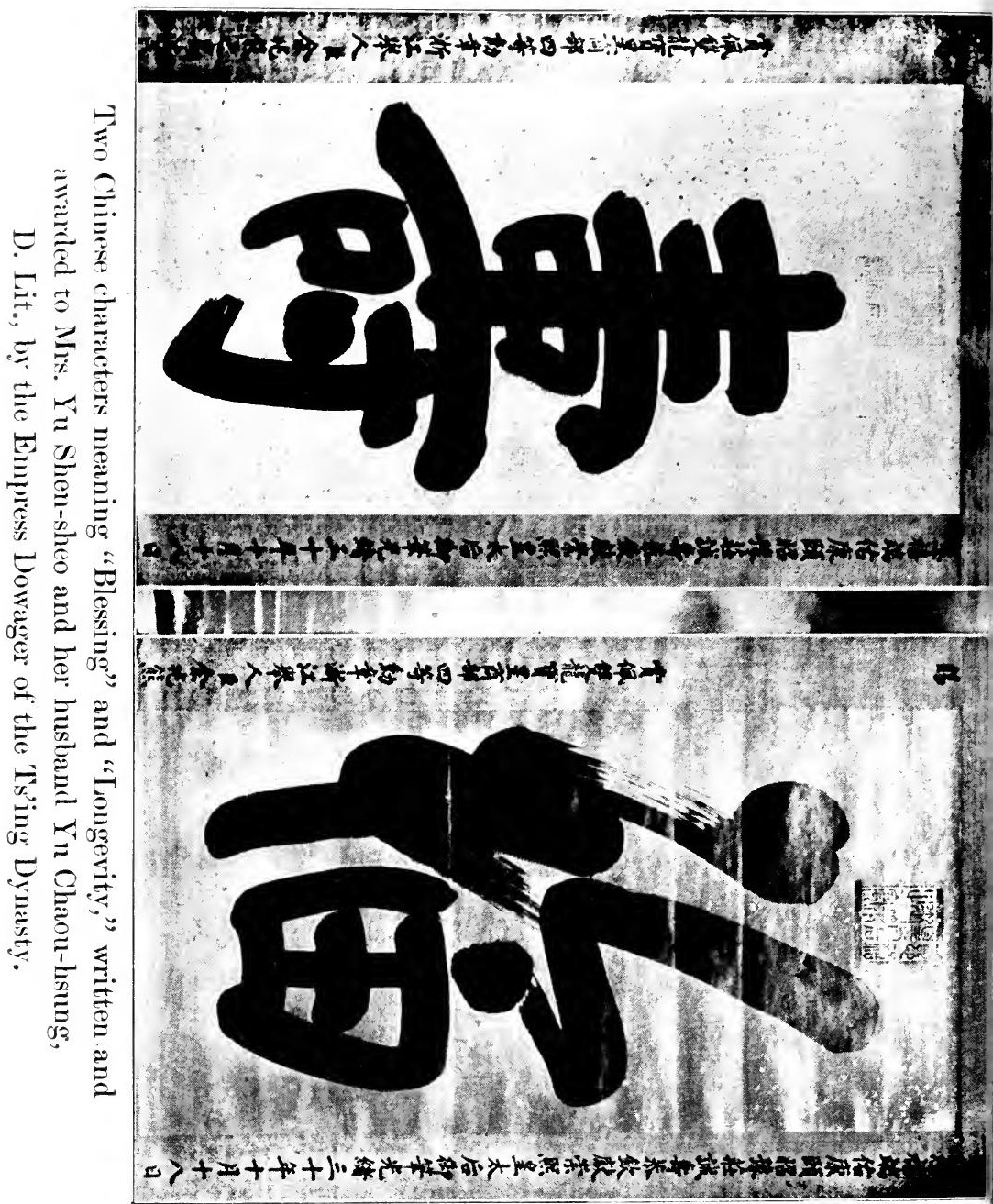

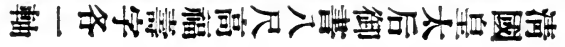




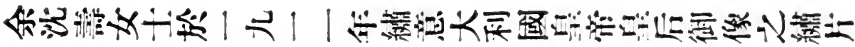

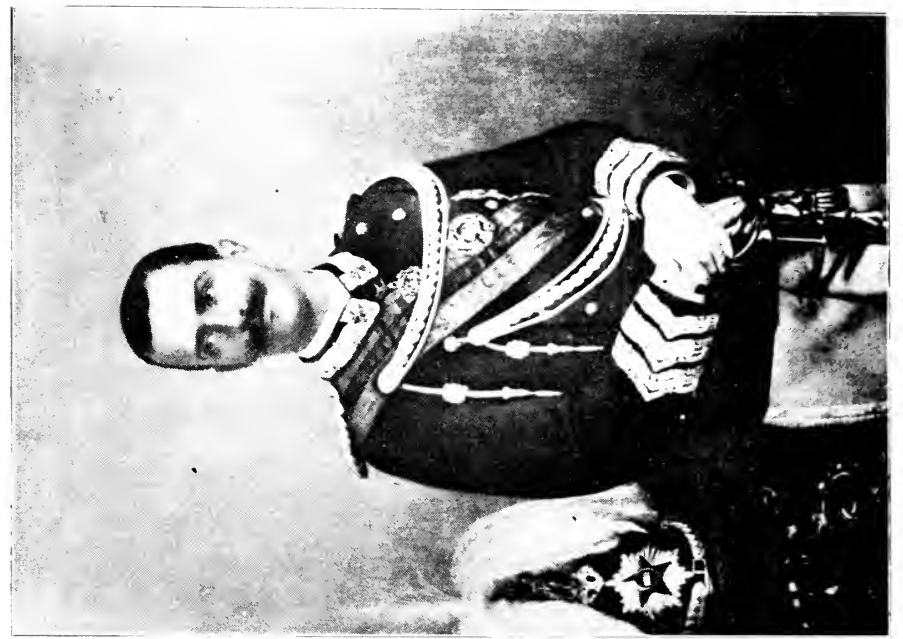

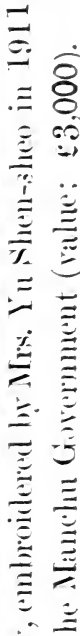

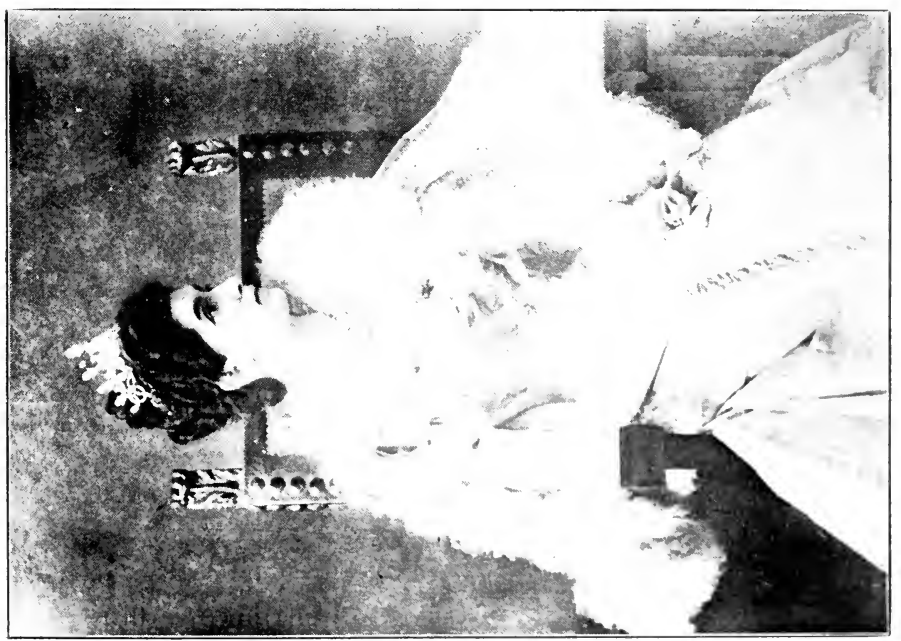

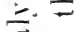

焉

$\overrightarrow{3}=$

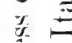

$\stackrel{\Xi}{\Xi}$

三

$\equiv \equiv$

$\exists$

$\because \div$

$\Xi \equiv$

$\equiv=$

$\underset{7}{7}$

$\doteq \equiv$

$=\overline{3}$

$\Xi$

$\because=$

吾

$\vdots$

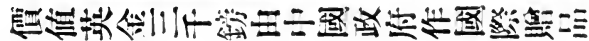




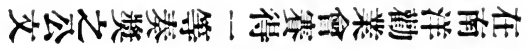

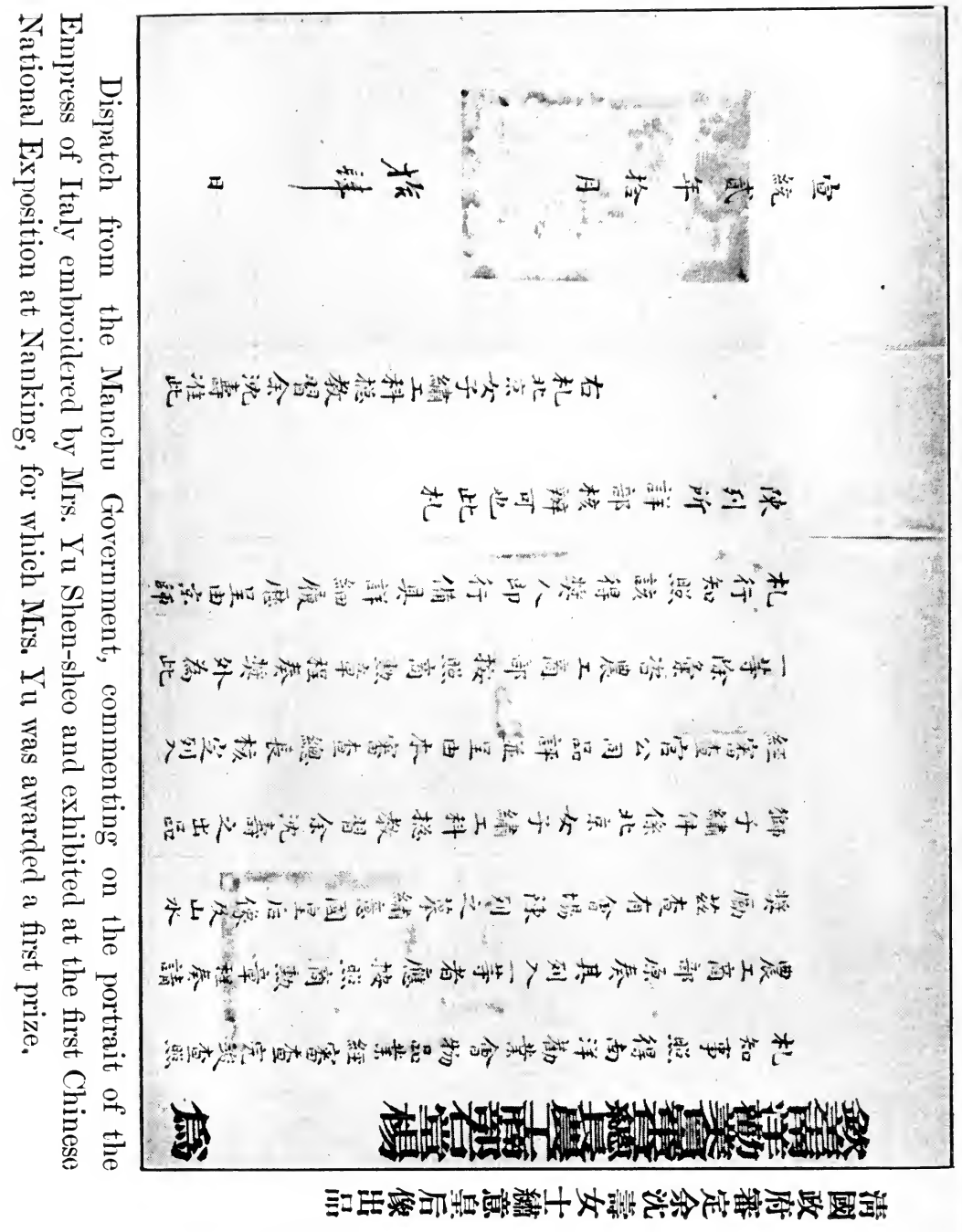


會覽博國萬朗都國利大意在品紼士女壽沈余 憑獎絕卓之級高最譽策大至界世得寒

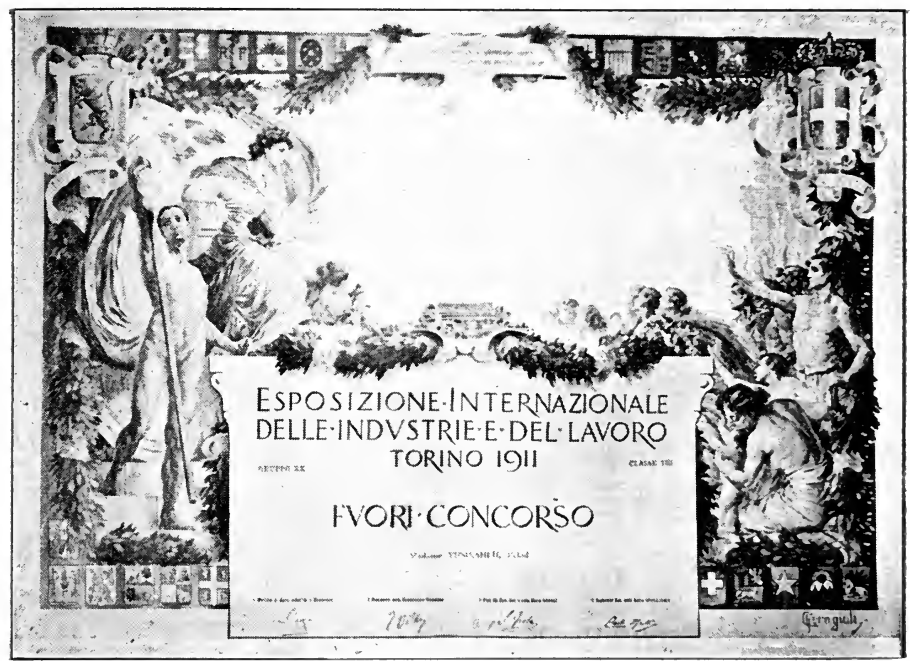

Diploma for the Grand Prize from the International Exposition in Italy, awarded to Mrs. Yu Shen-sheo for her embroidery work. 


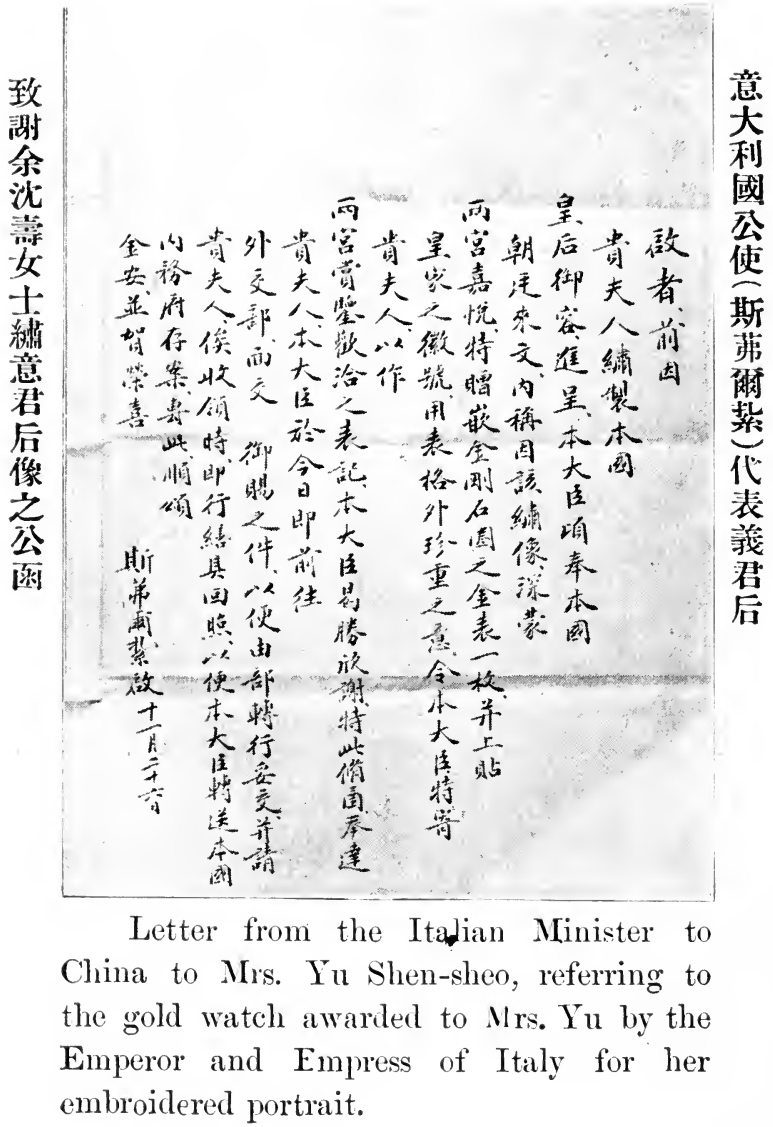




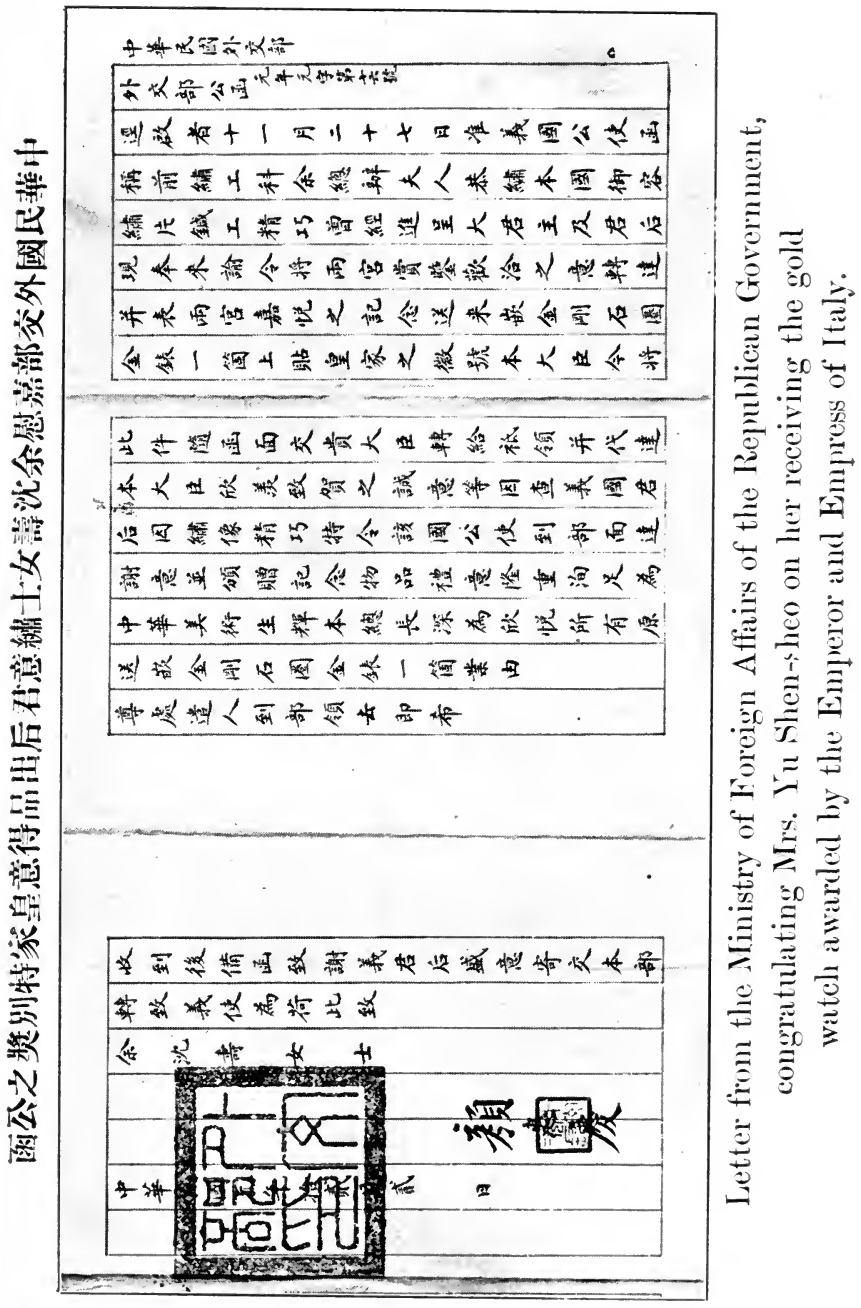




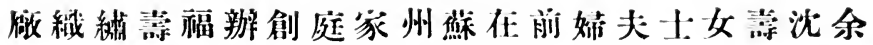
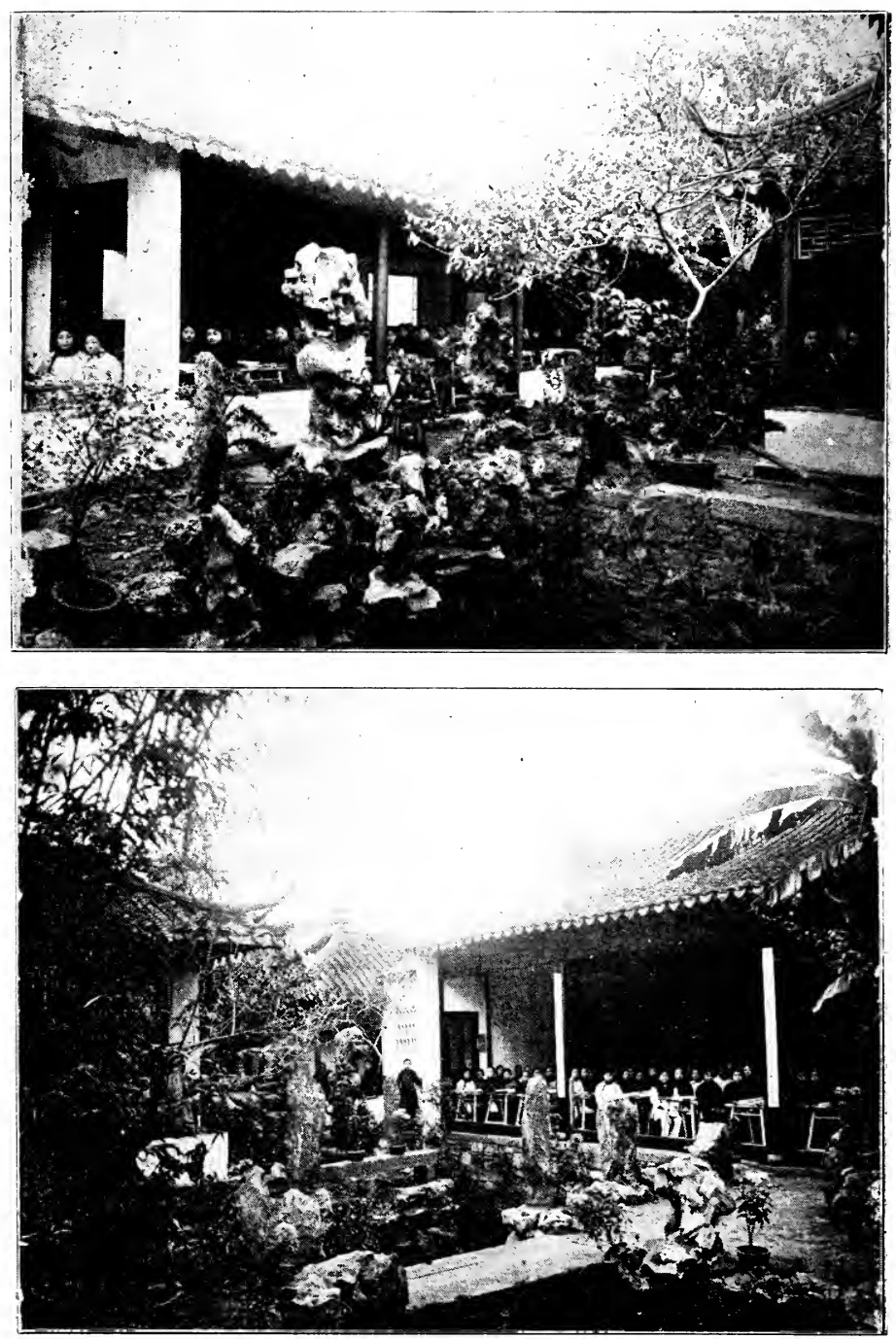

The "Fuh Shou" Embroidery Institute in Soochow, founded by Mrs. Yu She:-sheo and her husband. 


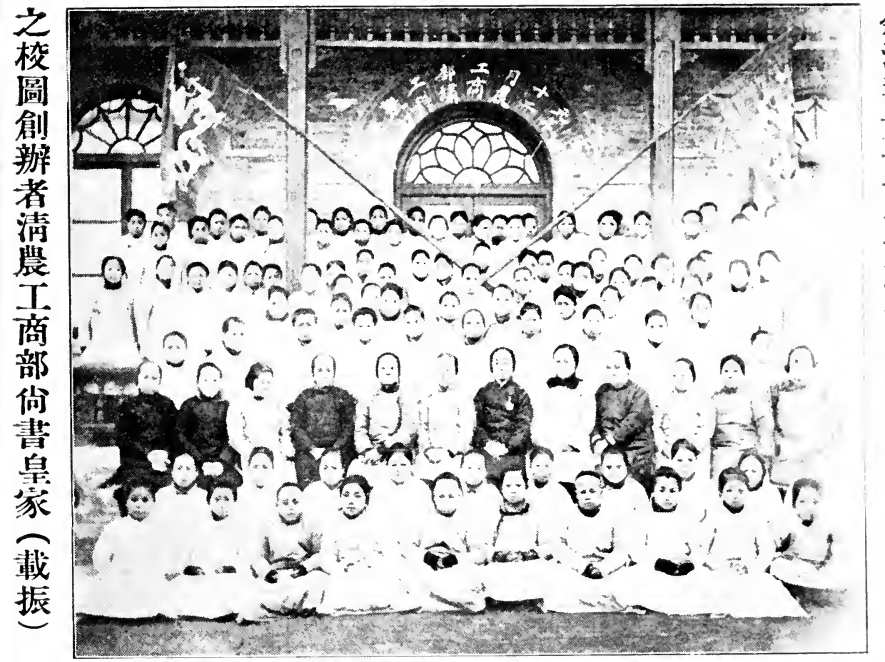

余

沈

管

女

1 .

胉

无

北

京

皇

家

美

㭪

䋳

I.

科

總

教

确

The Imperial Embroidery School, Peking, founded by

Prince 'Tsai Chen of the 'Ts'ing Dynasty; of which

Mrs. Yin Shen-sheo was the headmistress.

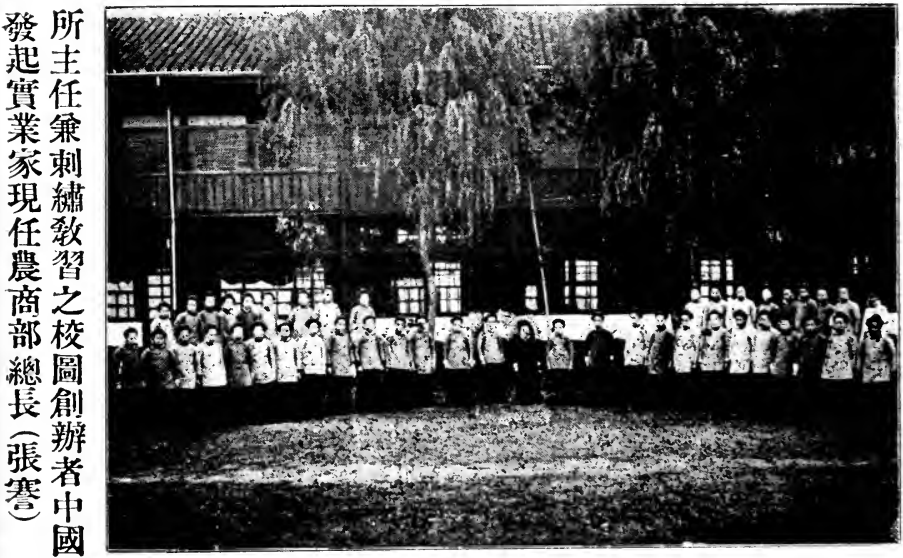

余

沈

意部

女

士.

現

允

江.

蕉

消

通

州

女

T.

傅

赖

'The Girls' Industrial school. 'Tungehow, of which

H. E. Chang Chien is the founder and Mrs. Yu Shen-sheo the healmistress and teacher in embroidery. 


\section{Other embroidered articles for the 1915 Panama Exposition}

\section{The Soochow Students,}

CNDER THE SLPERVISION OF

Mrs. Yu Shen-sheo, EXHIBITED BY

\section{H. E. Chang Chien,}

Minister of Agriculture and Commerce. 


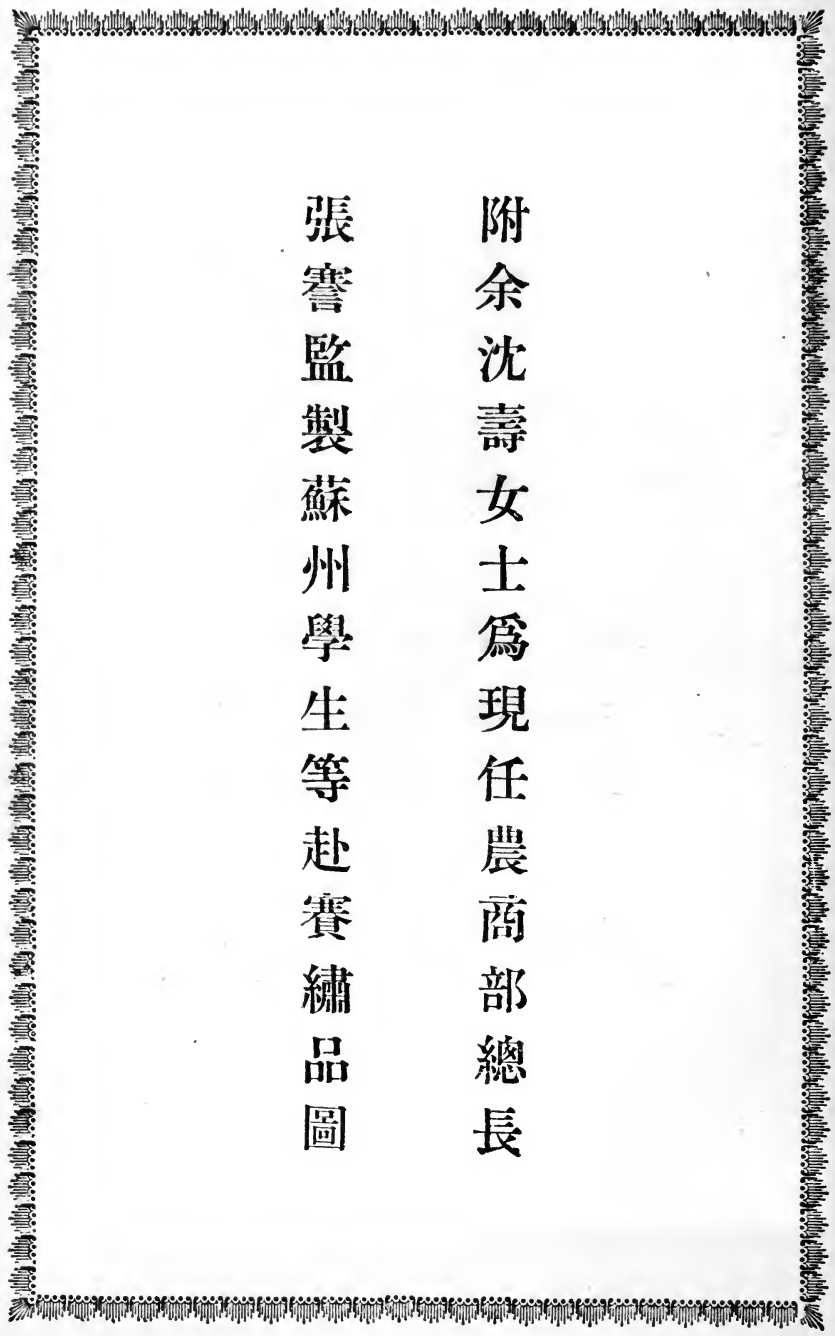




\section{像省(寒張)長總部商農任現家業實起墢國中人品出}

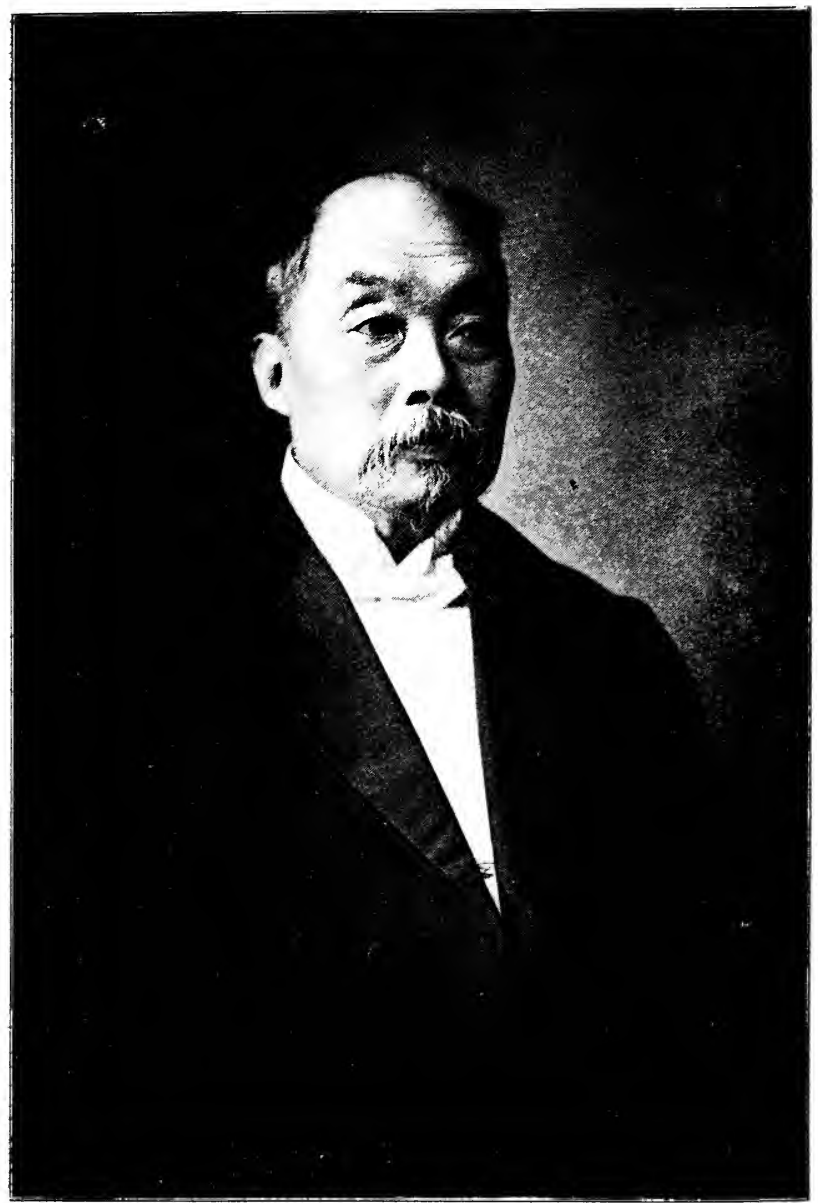

Portrait of H. E. Chang Chien, Minister of Agriculture and Commerce and the Foremost Industrial Prom oter of Chint. 

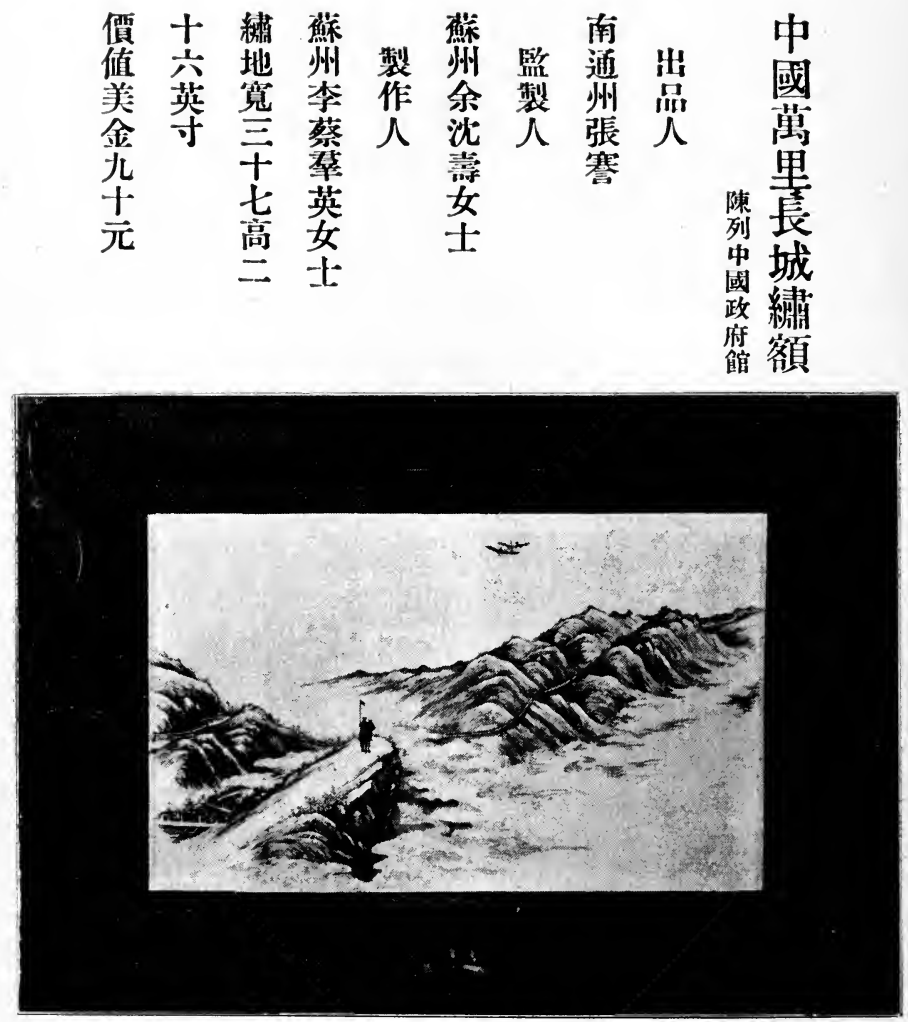

The Great Wall of China.-An Embroidered Picture. Embroiderer: Mrs. Lee Tsai-chun, Soochow. Supervisor: Mrs. Yu Shen-sheo, Soochow. Exhibitor: H. E. Chang Chien, Tungchow, Kiangsu. Size: $37^{\prime \prime} \times 26^{\prime \prime}$. Value: $\$ 90$. 

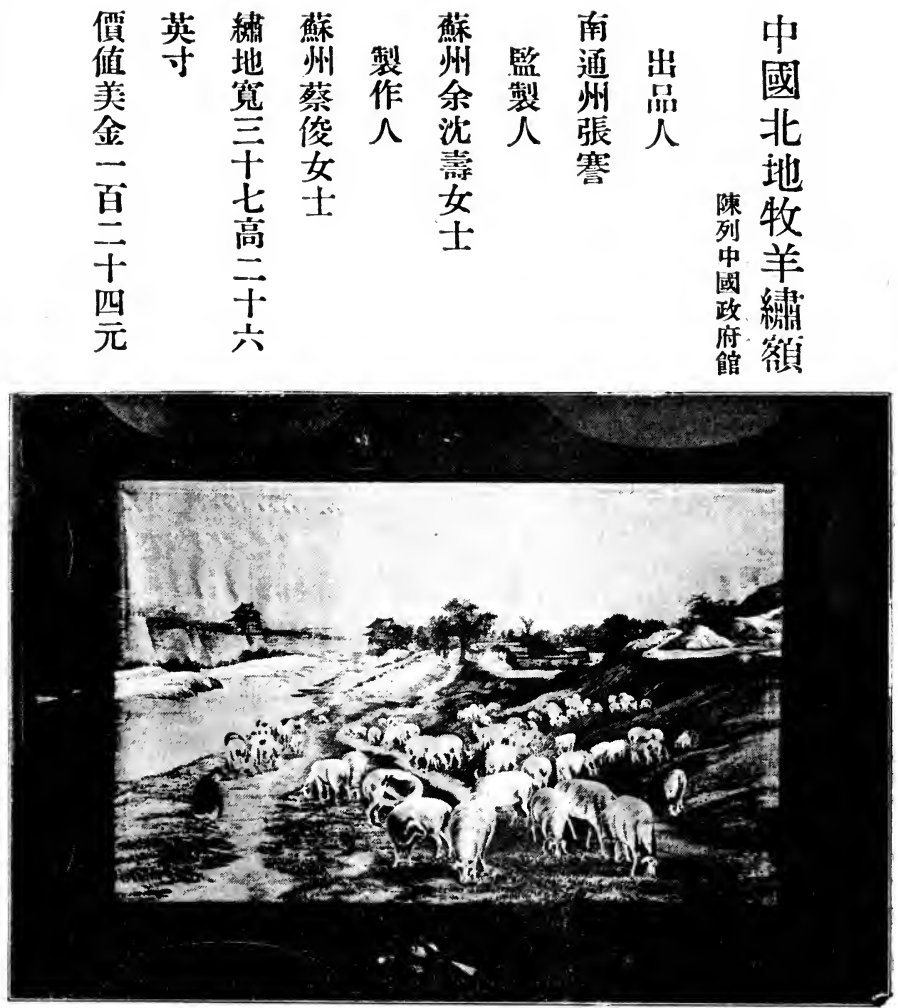

A Pastoral Scene in North China.-An Embroidered Picture.

Embroiderer: Miss Tsai Tseun, Soochow. Supervisor: Mrs. Yu Shen-sheo, Soochow. Exhibitor: H. E. Chang Chien, Tungehow, Kiangsu. - Size: $37^{\prime \prime} \times 26^{\prime \prime}$. Value: \$124. 


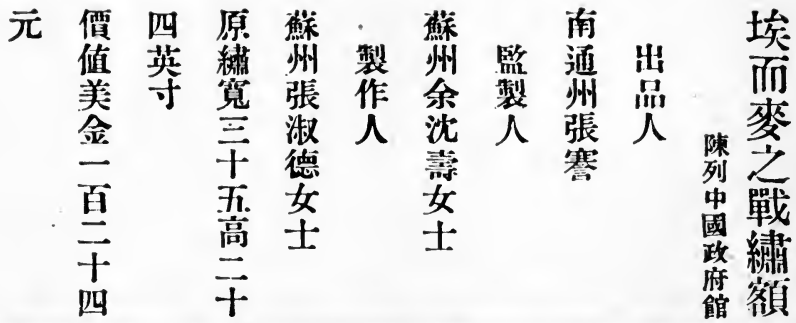

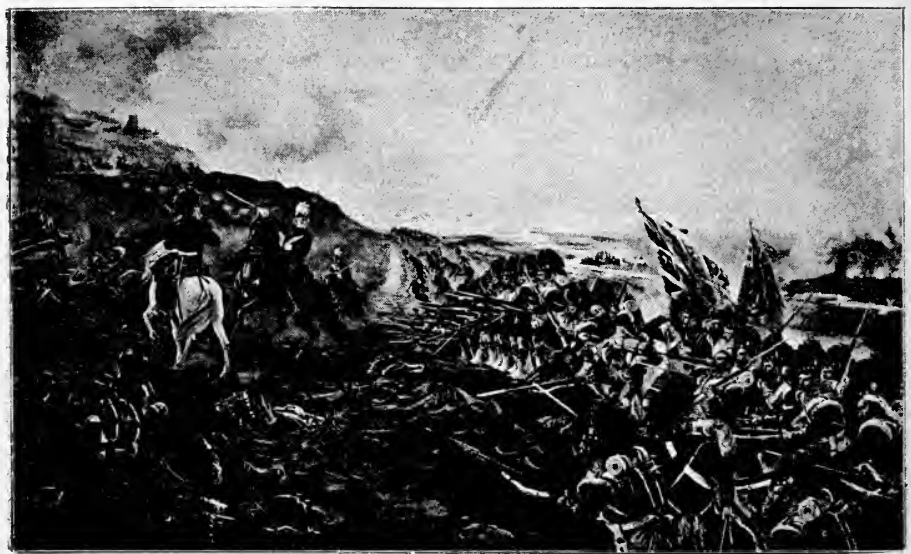

Battle of the Alma.-An Embroidered Picture.

Embroiderer: Miss Chang Shuh-teh, Soochow.

Supervisor: Mrs. Yu Shen-sheo, Soochow.

Exhibitor: H. E. Chang Chien, Tungehow, Kiangsu. Size: $35^{\prime \prime} \times 24^{\prime \prime}$. Value: $\$ 124$. 


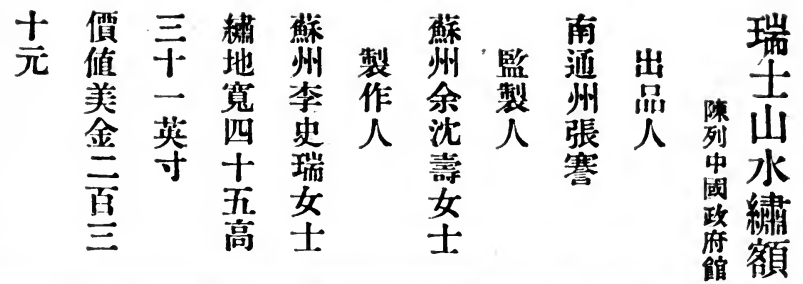

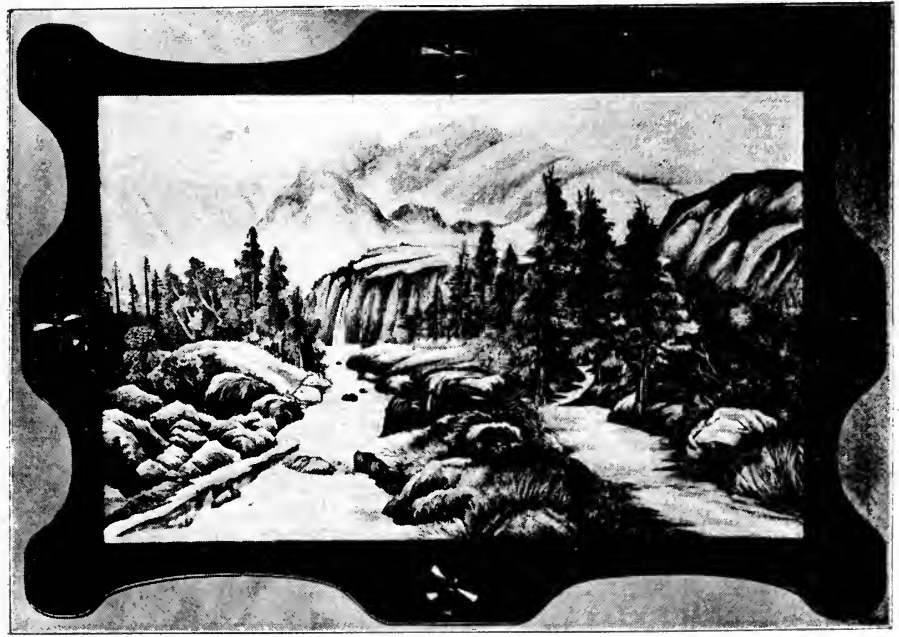

A Swiss Landscape - An Embroidered Picture.

Embroiderer: Miss I.ee Sze-shui, Soochow. Supervisor: Mrs. Yu Shen-sheo, Soochow. Exhibitor: H. E. Chang Chien, Tungchow, Kiangsu. Size: $45^{\prime \prime} \times 31^{\prime \prime}$. Value: $\$ 230$. 


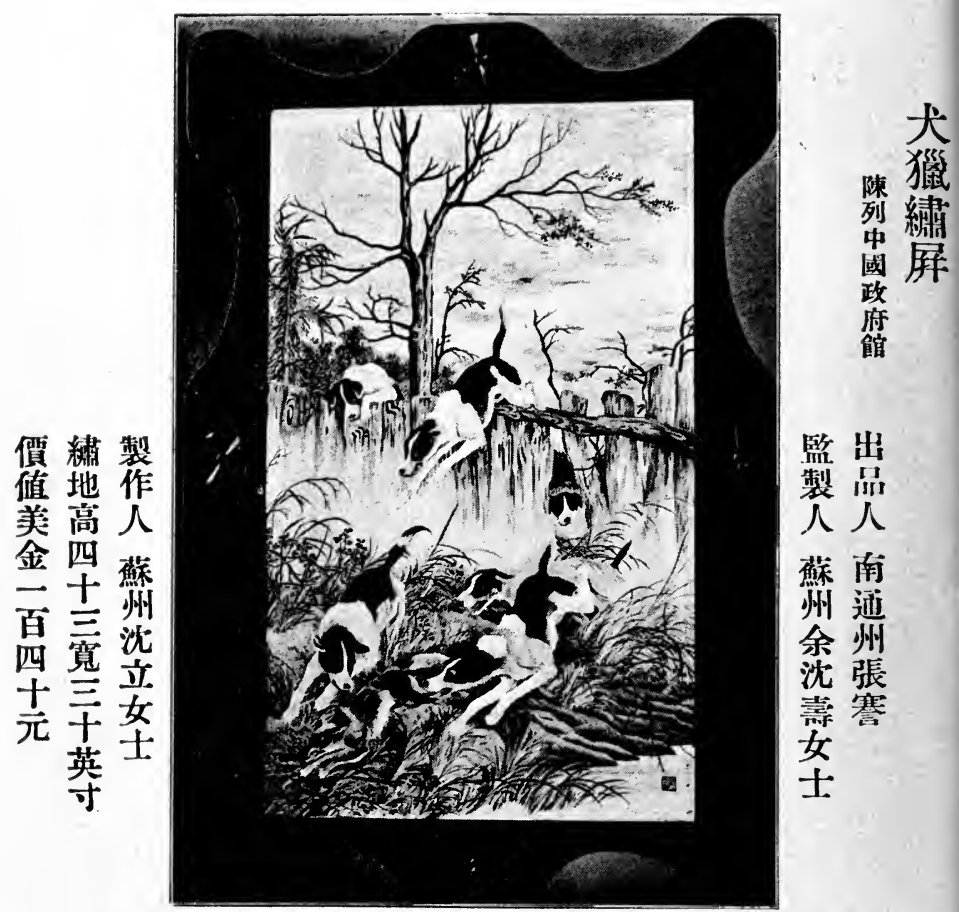

Hunting with Dogs.-An Embroidered Picture.

Embroiderer: Miss Shen Lih, Soochow.

Supervisor: Mrs. Yu Shen-sheo, Soochow.

Exhibitor: H. E. Chang Chien, Tungchow, Kiangsu Size: $43^{\prime \prime} \times 30 "$. Value: $\$ 140$. 

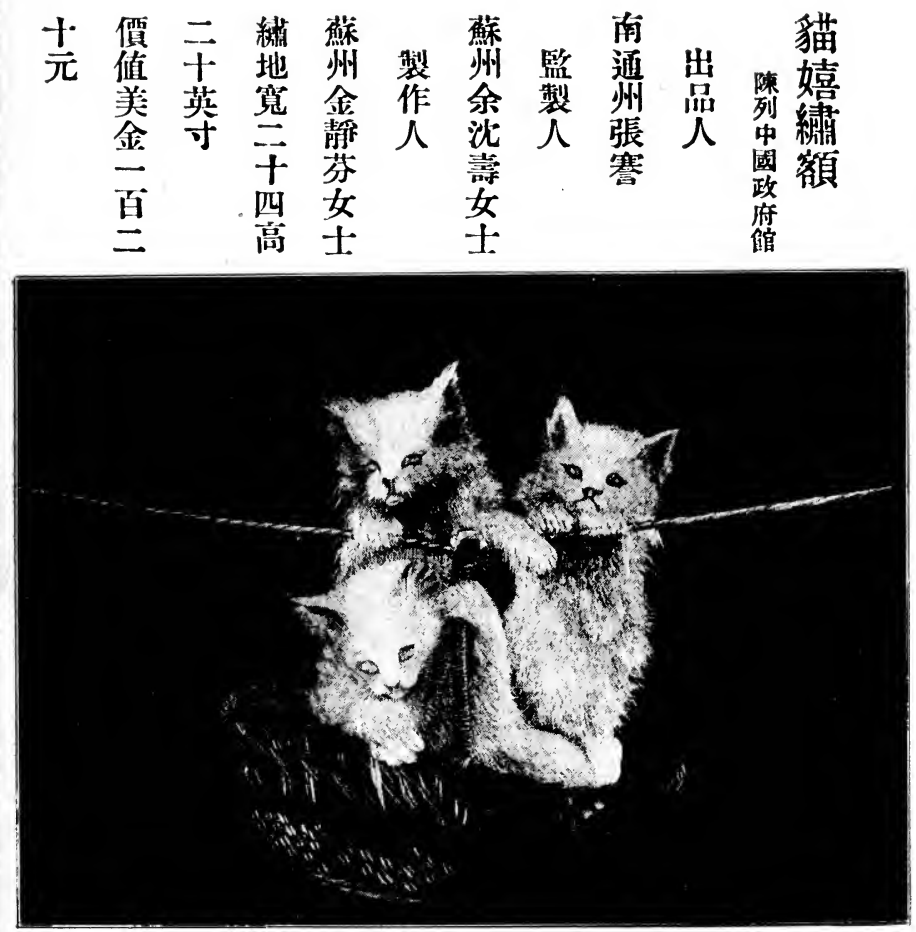

The Gambolling Cats._An Embroidered Picture.

Embroiderer: Miss King Tsing-fun, Soochow.

Supervisor: Mrs. Yu Shen-sheo, Soochow.

Exhibitor: H. E. Chang Chien, Tunchow, Kiangsu.

Size: $24^{\prime \prime} \times 20^{\prime \prime}$. Value: $\$ 120$. 

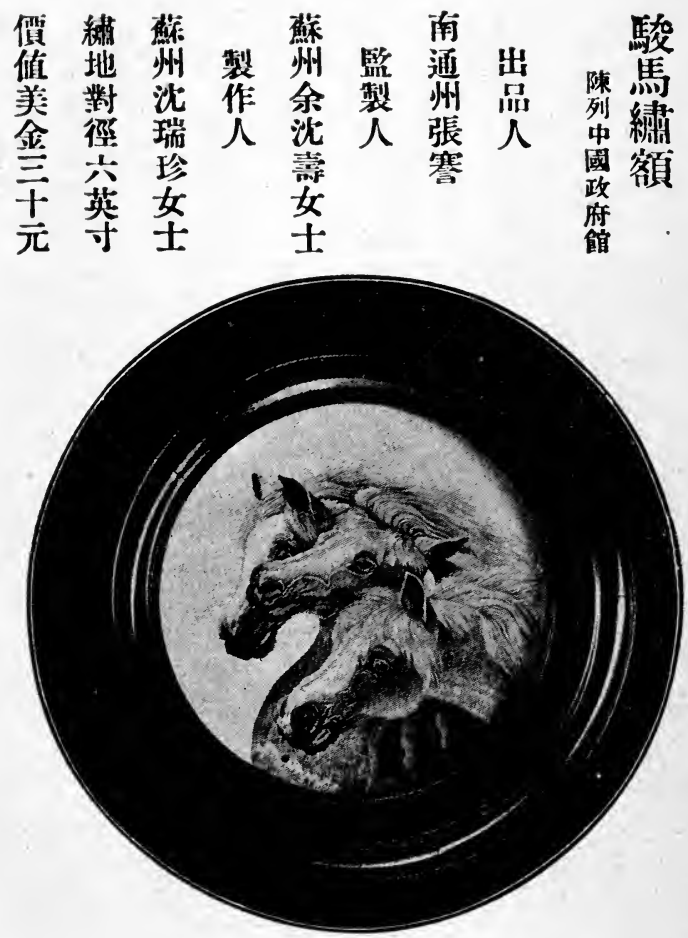

The Spirited Horses.-An Embroidered Picture.

Embroiderer: Miss Shen Shui-tseng, Soochow. Supervisor: Mrs. Yu Shen-sheo, Soochow.

Exhibitor: H. E. Chang Chien, Tungchow, Kiangsu.

Diameter: $6^{\prime \prime}$. Value: $\$ 30$. 
辦創勳商等四人舉學文夫丈之士女(㗲沈余)

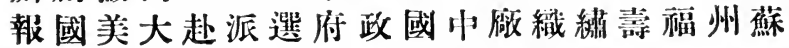

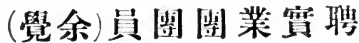

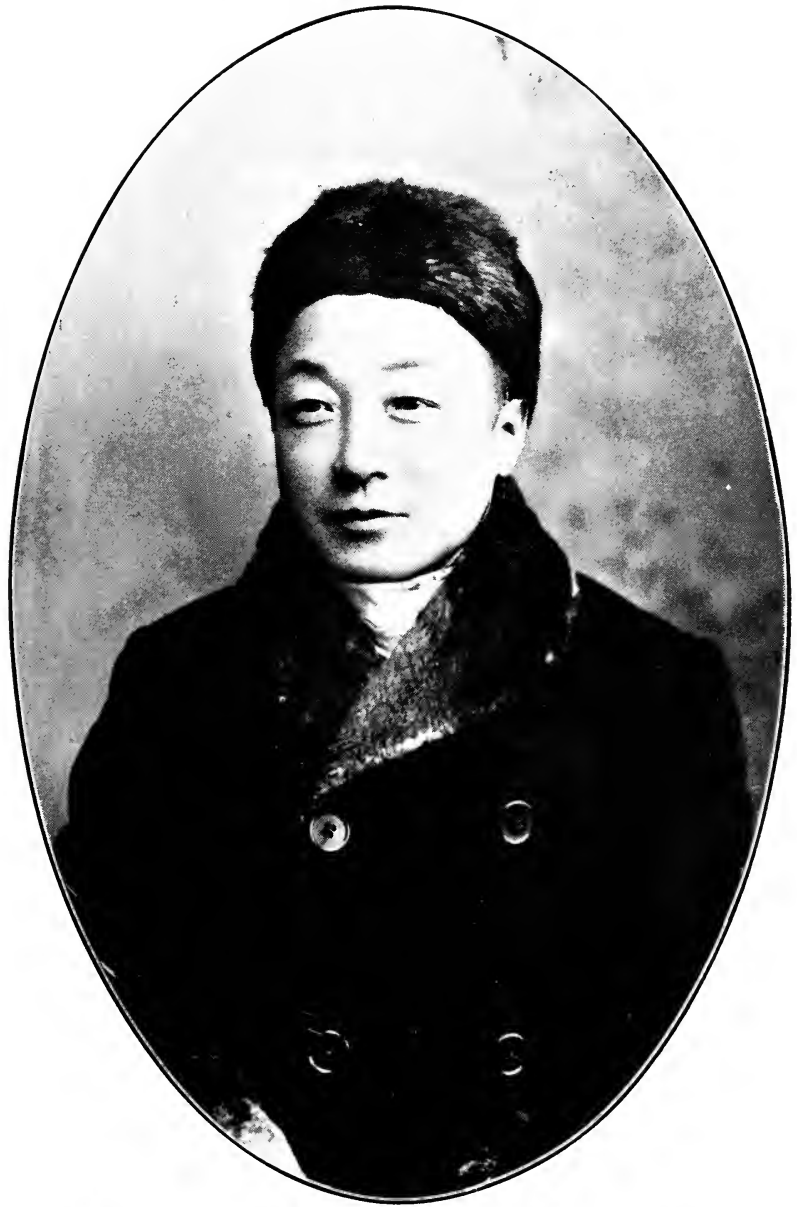

Mr. Yu Chio, I). Litt., husband of Mrs. Yu Shen-sheo; receiver of the Decoration of the Fourth Grade: founder of the Fuh shou Embroidery Institute at Soochow; and special delegate appointed by the Chinese Govermment to the Panama International Exposition. 

i)

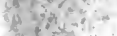

$3 x^{2}{ }^{2}=3 \therefore$

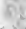

$\left(y^{2}+2=0\right.$.

$4,+20$

6.

$x^{2}=y^{4}$

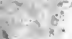

$5,5=$

\section{$-$}

$\therefore=2-51:$

3

8
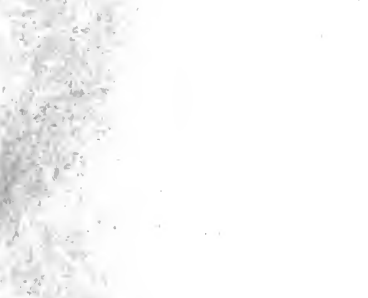

+4.

$+2$

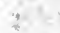

14

40

the

$-$

34

(4)

$5+x^{2}+6$ 
THIS BOOK IS DUE ON THE IAAST DATE STAMPED BELOW

AN INITIAL FINE OF 25 CENTS WILL BE ASSESSED FOR FAILURE TO RETURN THIS BOOK ON THE DATE DUE. THE PENALTY WILL INCREASE TO 50 CENTS ON SEVENTH DAY DAY AND TO \$1.00 ON THE OVERDUE.

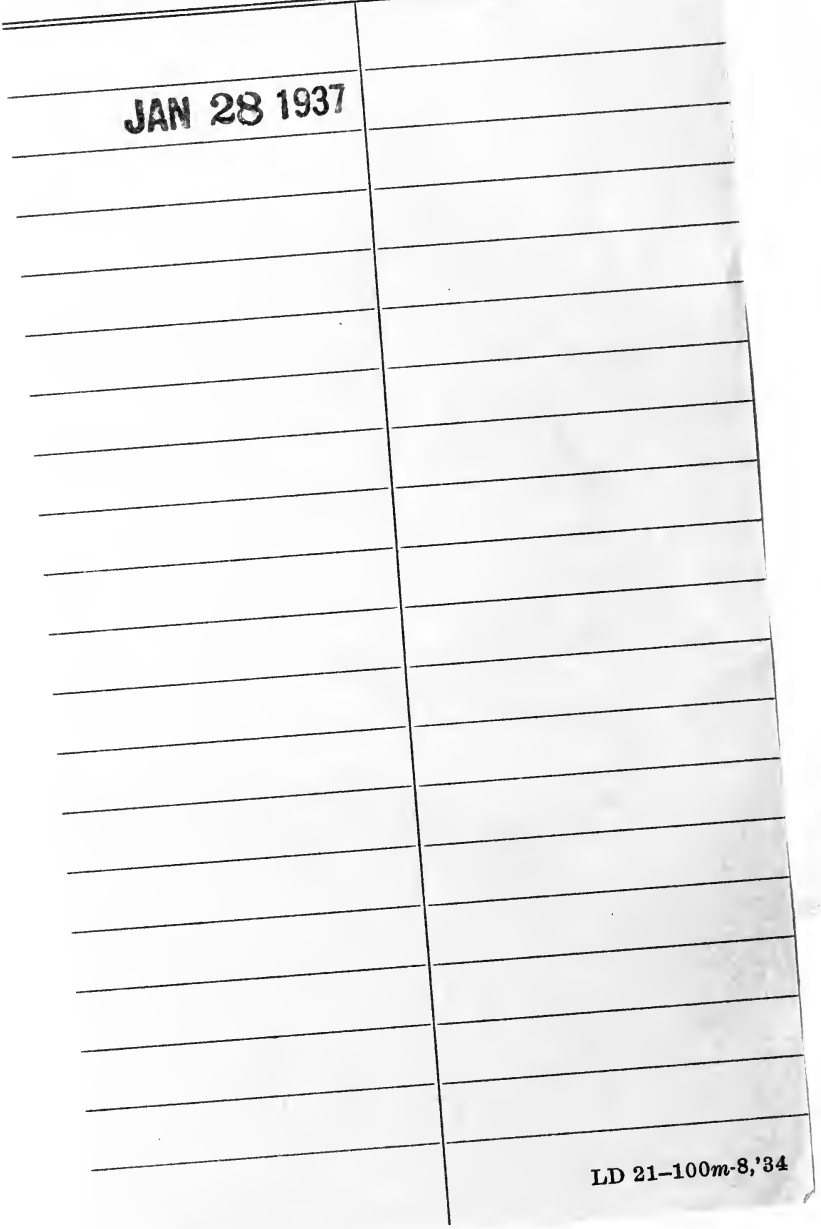


Gaylord Bros. Makers

Syracuse, N. Y. PAT. JAN 21, 1908

\section{8}

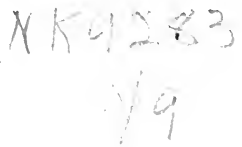

UNIVERSITY OF CALIFORNIA LIBE 
